\title{
Antioxidant and Phytochemical Test of Ziziphus mauritiana Ethanol Extract
}

\author{
Nurul Hidajati*, Siti Nafsiyah Rokhmania \\ Department of Chemistry \\ Universitas Negeri Surabaya \\ Surabaya, Indonesia \\ nurulhidajati@unesa.ac.id
}

\begin{abstract}
Ziziphus mauritiana is one of the plants that can grow in Indonesia. Many of these plants have potential antioxidant compounds. $Z$. mauritiana ethanol extract was obtained through maceration of ziziphus mauritiana bark, toward the extract was then continued to do phytochemical screening and antioxidant activity testing using DPPH method. The phytochemical screening results shown that the extract contains a classes of compound are alkaloid, flavonoid, phenolic, saponin, and tannin. It was known that $\mathrm{IC}_{50}$ value of ethanol extract was $75.8304 \mathrm{ppm}$.
\end{abstract}

Keywords-antioxidants, DPPH, phytochemicals, phenolics, Ziziphus mauritiana

\section{INTRODUCTION}

Free radicals form the basis of various biochemical reactions and play an important role in the aerobic and metabolic systems. Free radicals in the body are produced continuously through enzymatic and non-enzymatic reactions such as respiration reactions, phagocytosis, prostaglandin synthesis, the cytochrome P450 system and oxidative phosphorylation (aerobic respiration) in the mitochondria. In addition, free radicals are also found in the environment such as pollutants, cigarette smoke, pesticides and others. Antioxidant is a substance which at a small concentration can significantly inhibit or prevent oxidation on the substrate [3]

Ziziphus mauritiana is known by various names in several regions in Indonesia such as Bidara (Java, Sunda), Bekul (Bali), Kalangga (Sumba), and Rangga (Bima) [2]. Ziziphus mauritiana plants as a whole contain several classes of compounds such as flavonoids, alkaloids, glycosides, saponins, resins, polyphenols, mucilago and vitamins [2]. Z. mauritiana fruit screening results showed flavonoids, glycosides, phenols, lignins, saponins, and tannins [6]. Phytochemical screening of ethanol extracts of $Z$. mauritiana seeds contains alkaloids, terpenes, tannins, flavonoids, saponins, sterols, and phytosterols [5]. Phytochemical screening of $Z$. mauritiana root extract revealed the presence of alkaloids, flavonoids, glycosides, saponins, and essential oils and in phytochemical screening stem extracts showed the presence of alkaloids, anthocyanins, anthracene glycosides, antraquinones, aukubins iridoids, carbohydrates, cardiac glycosides, carotenoids, emoticons, carotenoids, emoticons flavonoids, polyuronoids, saponins, starches, steroids, tannins, and triterpenoids [8].
[4] reported that ethanol-water extract of Z. mauritiana was identified to contain flavonoid compounds namely naringenin triglycoside, myricetin 3-O-galactoside, quercetin 3-O-pentosylhexoside, quercetin 3-O-robinobioside, quercetin 3-O-galactoside, quercetin 3-O-pentosylhexoside, quercetin 3-O-robinobioside, quercetin 3-O-galactoside routineoside, quercetin 3-O-galactoside, quercetin 3-Oglucoside, quercetin 3-O-rhamnoside, quercetin 3-O-6 'malonylglucoside, quercetin 3-O-malonylglucoside, luteolin 7-O-malonylglucoside, and luteolin 7-O-6-'malonyl glucoside. [4] also succeeded in isolating 9 phenolic acids, namely protocatechuic acid, $p$-hydroxybenzoic acid, ferulic acid, chlorogenic acid, vanillic acid, caffeic acid, vanillin, ortho-and para-coumaric acids, and successfully isolating 3 main phenolic acids namely $p$-coumaric acid, vanillin and ferulic acids. [7] succeeded in identifying compounds contained in Z. mauritiana fruit, namely lipid compounds, phenolic compounds of flavanol and flavonol groups, and condensed tannin compounds. This research is based on testing the antioxidant activity and phytochemical testing of Z. mauritiana ethanol extract.

\section{RESEARCH MATERIALS AND PROCEDURES}

Material used in this research are Z. mauritiana bark, ethanol $96 \%$, methanol, sulfuric acid, filter paper, $\mathrm{HgCl}_{2}$, $\mathrm{KI}$, distilled water, $\mathrm{Bi}\left(\mathrm{NO}_{3}\right)_{2}, \mathrm{HNO}_{3}, \mathrm{I}_{2}, \mathrm{HCl} 2 \mathrm{~N}$, acetic anhydrous, concentrated $\mathrm{H}_{2} \mathrm{SO}_{4}, \mathrm{FeCl}_{3} 1 \%, 70 \%$ ethanol, $\mathrm{Mg}$ band, concentrated $\mathrm{HCl}, 1 \mathrm{~N} \mathrm{HCl}, 10 \% \mathrm{NaCl}, 1 \%$ gelatin, and DPPH. The tools used in this research are Buchner funnel, pipette, analytical balance, micropipette, measuring flask, vial, test tube, and UV-Vis spectrophotometer (Shimadzu UV-1800).

\section{A. Z. Mauritiana Extraction}

Samples in the form of $4 \mathrm{~kg}$ fine bark powder were extracted by maceration method using $96 \%$ ethanol until the sample was submerged $\pm 1 \mathrm{~cm}$ against the solvent. Maceration is done for $1 \times 24$ hours and repeated 3 times. Then filtering is done using a Buchner funnel so that the resulting filtrate and residue. Furthermore, the filtrate obtained was evaporated using a vacuum rotary evaporator to produce a thick ethanol extract.

\section{B. Phytochemical Screening}

The ethanol extract of $Z$. mauritiana bark was tested by phytochemicals as follows:

1) Phenolic 
$1 \mathrm{ml}$ Ethanol extract is added with $0.5 \mathrm{~mL}$ methanol $60-70 \%$ and 10 drops of $1 \% \mathrm{FeCl}_{3}$ solution. A positive test for the presence of phenolic compounds is displayed the formation of red, blue, purple, black or green [1]

\section{2) Flavonoids}

$1 \mathrm{~mL}$ of Ethanol extract was mixed with $3 \mathrm{~mL}$ of $70 \%$ ethanol, then shaken, heated in a water bath, and shaken again then filtered. The filtrate was added with 0.1 gram $\mathrm{Mg}$ band and 2 drops of concentrated $\mathrm{HCl}$. Positive tests containing flavonoid are characterized by changing red color [1].

3) Saponins

$1 \mathrm{ml}$ Ethanol extract was mixed with $2 \mathrm{~mL}$ of distilled water and shaken until homogeneous. The mixture was then heated for 2-3 minutes and cooled and shaken vigorously. Positive result for saponin if a stable foam is formed \pm 7 minutes [1].

4) Tanin

$1 \mathrm{ml}$ Ethanol extract was added by 5 drops of $10 \%$ $\mathrm{NaCl}$ and filtered. The filtrate obtained was added with $1 \%$ gelatin and $10 \% \mathrm{NaCl}$. A positive test for the presence of tannin is characterized by the presence of white precipitate [1].

5) Steroids and Triterpenoids

$1 \mathrm{ml}$ Ethanol extract was added by $\left(\mathrm{CH}_{3} \mathrm{CHO}\right)_{2} \mathrm{O}$ and concentrated $\mathrm{H}_{2} \mathrm{SO} 4$. The presence of steroid is indicated by the formation of green or blue color. The presence of triterpenoid is indicated by the formation of golden yellow, yellow, or purple [1].

6) Alkaloids

$1 \mathrm{ml}$ Ethanol extract was added by 5 drops of concentrated ammonia and then filtered and added $2 \mathrm{~mL}$ of $2 \mathrm{~N}$ sulfuric acid. The mixture was then divided into 3 different tubes. Each tube was dropped by 1 drop of Mayer reagent in the first tube, in the second tube 1 was dropped by Dragendorff's reagent, and in the third tube 1 was dropped by Wagner's reagent. The presence of alkaloid if the addition of the Mayer reagent formed yellow precipitate, the addition of the Dragendorff reagent formed red precipitate, and on the addition of Wagner reagent a brown or red precipitate was formed [1].

\section{Antioxidant Activity Test}

Sample solutions with concentrations of $6.25,12.5,25$, 50 , and $100 \mathrm{ppm}$ each were piped $300 \mu \mathrm{L}$ and put into vials, each vial was added by $3 \mathrm{~mL}$ of DPPH $0.004 \%$ solution in methanol. The mixture is then shaken and allowed to stand in a dark room for 30 minutes. The solution is then tested for absorbance with a UV-Vis spectrophotometer with optimum wavelength. Each sample concentration was repeated 3 times. Then the results were analyzed by determining the $\mathrm{IC}_{50}$ value. The same procedure was carried out for vitamin $\mathrm{C}$ as a positive control.

\section{RESULT AND DISCUSSION}

Based on the results of phytochemical screening on ethanol extract $Z$. mauritiana shown in Table 1.

TABLE I. PHYTOCHEMICAL SCREENING RESUlts OF ETHANOL EXTRACT OF Z. MAURITIANA

\begin{tabular}{|c|c|c|}
\hline $\begin{array}{c}\text { Phytochemical } \\
\text { Test }\end{array}$ & Color Caused & $\begin{array}{c}\text { Phytochemical } \\
\text { Analysis } \\
\text { Results } \\
(+/-) \\
\end{array}$ \\
\hline Alkaloids & & + \\
\hline - $\quad$ Mayer & $\begin{array}{l}\text { white precipitate } \\
\text { formed }\end{array}$ & + \\
\hline - Wagner & $\begin{array}{l}\text { brown precipitate } \\
\text { formed }\end{array}$ & + \\
\hline $\begin{array}{ll}- & \text { Drage } \\
& \text { ndorff }\end{array}$ & $\begin{array}{l}\text { orange precipitate } \\
\text { formed }\end{array}$ & + \\
\hline Steroid & $\begin{array}{l}\text { Green and blue } \\
\text { color not formed }\end{array}$ & - \\
\hline Triterpenoid & $\begin{array}{l}\text { Brown color } \\
\text { formed }\end{array}$ & - \\
\hline Phenolic & $\begin{array}{l}\text { blackish purple } \\
\text { color formed }\end{array}$ & + \\
\hline Flavonoid & $\begin{array}{l}\text { Reddish color } \\
\text { formed }\end{array}$ & + \\
\hline Saponin & Stable foam formed & + \\
\hline Tanin & $\begin{array}{l}\text { white precipitate } \\
\text { formed }\end{array}$ & + \\
\hline
\end{tabular}

Information:

+ : Containing

-: Does not contain

In ethanol extract of $Z$. mauritiana through phytochemical screening known containing alkaloids. Alkaloid tests based on $\mathrm{K}^{+}$ions from test reagents (Mayer, Wagner, and Dragendorff) will bind to coordination with nitrogen atoms from the structure of alkaloid to form a precipitated potassium-alkaloid complex. The test results showed that ethanol extract contained alkaloids [9].

Steroid and triterpenoid test for $Z$. mauritiana ethanol extract showed negative result. Whereas the phenolic test showed a positive test which was marked by the formation of a blackish purple color caused by the formation of a complex compound between phenolic compounds with $\mathrm{Fe}^{3+}$ ions from $\mathrm{FeCl}_{3}$. Flavonoids are tested based on oxidation reduction reactions and complex formation with $\mathrm{Mg}^{2+}$ ions. Based on the flavonoid test, ethanol extract of $Z$. mauritiana showed containing flavonoids which are characterized by reddish color. Saponin test showed positive on ethanol extract of $Z$. mauritiana which was characterized by the emergence of a stable foam hydrolysis of saponin nto glycone and aglycone compounds. While the tannin test also showed positive marked with white precipitate formed.

For a while, the results of the antioxidant test of $Z$. mauritiana ethanol extract is shown in Table 2. 
TABLE II. THE RESUlTS OF ANTIOXIDANT ACTIVITY TEST OF ETHANOL EXTRACT OF Z. MAURITIANA

\begin{tabular}{|c|c|c|c|}
\hline Sample & $\begin{array}{c}\text { Concentration } \\
(\mathbf{p p m})\end{array}$ & $\begin{array}{c}\text { \% } \\
\text { Inhibition }\end{array}$ & \\
\hline \multirow{3}{*}{$\begin{array}{c}\text { ICthanol } \\
\text { extract of } Z . \\
\text { mauritiana }\end{array}$} & 6.25 & 6.708 & \multirow{1}{*}{} \\
\cline { 2 - 3 } & 12.5 & 12.332 & \\
\cline { 2 - 3 } & 25 & 21.775 & \multirow{2}{*}{75.8304} \\
\cline { 2 - 3 } & 50 & 39.215 & \\
\hline & 100 & 61.868 & \\
\cline { 2 - 3 } & 1 & 39.154 & \multirow{2}{*}{8.134} \\
\cline { 2 - 3 } & 5 & 47.81 & \\
\cline { 2 - 3 } Vitamin C & 10 & 50.126 & \\
\cline { 2 - 3 } & 15 & 55.561 & \\
\cline { 2 - 3 } & 20 & 74.081 & \\
\hline
\end{tabular}

The principle of testing using the DPPH method is based on the ability of antioxidant compounds to donate protons to free radical compounds. The smaller the $\mathrm{IC}_{50}$ value, the stronger the ability of a compound as an antioxidant. The results of measurement of antioxidant activity obtained IC50 value of ethanol extract of $Z$. mauritiana was $75.8304 \mathrm{ppm}$ while $\mathrm{IC}_{50}$ Vitamin $\mathrm{C}$ was 8.134 ppm.

\section{CONCLUSION}

The ethanol extract of Z. mauritiana contains alkaloid, phenolic, flavonoid, saponin, and tannin. It was reported that $\mathrm{IC}_{50}$ value of ethanol extract against $\mathrm{DPPH}$ was 75.8304 ppm.

\section{REFERENCES}

[1] Harbone, J. B. 1987. Metode Fitokimia penuntun Cara Modern Menganalisis Tumbuhan. Bandung: Penerbit ITB.

[2] Hariana, A. 2006. Tumbuhan Obat dan Khasiatnya, Seri 3. Jakarta: Penebar Swadaya.

[3] Isnidar, Subagus Wahyuono., dan Setyowati, Erna Prawita. 2011 Isolasi dan Identifikasi Senyawa Antioksidan Daun Kesemek (Diospyros kaki Thumb.) dengan Metode DPPH (2,2-Difenil-1pikrilhidrazil). Majalah Obat Tradisional. 16(3), 157-164.

[4] Memon, Ayaz Ali , Najma Memon, Muhammad Iqbal Bhanger, and Devanand L. Luthria. 2013. Assay of Phenolic Compounds from Four Species of Ber (Ziziphus Mauritiana L.) Fruits: Comparison of Three Base Hydrolysis Procedure for Quantification of Total Phenolic Acids. Food Chemistry. 139. 96-502

[5] Mishra and Bathia. 2014. Chinee Apple Indian Jujube Ziziphus maurtiana. America: Queensland Government.

[6] Rathore, S., Bhatt, S., Suresh Dhyani, D., Jain, A., 2012. Preliminary Phytochemical Screening of Medicinal Plant Ziziphus mauritiana Lam Fruits. International Journal of Current Pharmaceutical Research. Volume 4.

[7] Suzie, Z., Adrien, S., Guillaume, C., Didier, A-M., Sylvie, R., Dominique, P., Abel, H., Changes in Antioxidant Activity During The Ripening of Jujube (Ziziphus mauritiana Lamk). Food Chemistry. 42, 131-136.

[8] Thomas, A.N.S. 2004. Tanaman Obat Tradisonal 2. Yogyakarta: Kanisius.

[9] Wardana, Andika Pramudya; Arwanda, Rika; Nabila, Sofi; Tukiran. 2015. Uji Skrining Fitokimia Ekstrak Metanol Tumbuhan Gowok (Syzygium polycephalum). Prosiding Seminar Nasional Kimia. Jurusan Kimia, Unesa 